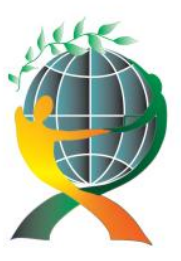

$$
\begin{gathered}
\text { (online) }=\text { ISSN 2285 - 3642 } \\
\text { ISSN-L = 2285 - 3642 } \\
\text { Journal of Economic Development, Environment and People } \\
\text { Volume 1, Issue 3, } 2012 \\
\text { URL: } \underline{\text { http://jedep.spiruharet.ro }} \\
\text { e-mail: } \underline{\text { office jedep@ spiruharet.ro }}
\end{gathered}
$$

\title{
Green Marketing and Sustainable Development - Experiences from Republic of Serbia
}

\author{
Branislav Radnovic, PhD \\ Faculty of Business Economy \\ Educons University, Sremska Kamenica - Novi Sad \\ Vojvode Putnika bb \\ Tel: +38121/4893-630 \\ E-mail: rabanyu@yahoo.com
}

Milena Ilic, Magistra

Public Utility Service „Gradsko stambeno“, Belgrade

Danijelova 33, Belgrade

Tel. $+38164 / 8950.416$

E-mail: milena.ilic@stambeno.com

Zoran D. Zivkovic, Msc

Public Utility Service „Gradsko stambeno“, Belgrade

Danijelova 33, Belgrade

Tel. $+38164 / 8950.277$

E-mail:zoran.zivkovic@stambeno.com 


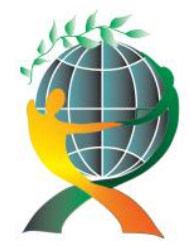

\author{
(online) $=$ ISSN $2285-3642$ \\ ISSN-L = $2285-3642$ \\ Journal of Economic Development, Environment and People \\ Volume 1, Issue 3, 2012 \\ URL: http://jedep.spiruharet.ro \\ e-mail: office jedep@spiruharet.ro
}

\begin{abstract}
The world must be developed according to the needs of people, but with the obligation of sustainable development as a comprehensive process that depress all aspects of life, at all levels.

Sustainable development is about making models in a qualitative way to meet the socio-economic needs and interests of citizens, while eliminating or significantly reducing the impacts that threaten or harm the environment and natural resources.

Sustainable development of mankind leads to a sustainable society in which man has good control of the planet and responsible custodian of heritage for future generations.

Sustainable development is without a doubt, as a result of the coming dramatic changes requested in all areas of life of every individual. Changes are related to the change in our spending habits (which in itself is already hard enough) and the change of consciousness in the fields of economics, politics and society.

Companies that are self-conscious to environment with potential for business and profits, also realize a significant contribution to environmental protection. These successful companies not only sell products to its customers and thus gain profits, but in the corporate commitment to make decisions for the care of their surroundings. In contrast to conventional producers, the most successful green companies direct their customers, or in advance know what needs to be made and the buyer offers an environmentally friendly product. Green companies are ready to address concerns about the natural environment.

Green marketing is the primary segment of social marketing, because it covers the protection and preservation of the values necessary for survival, existence and development of man as a human being, reflecting the practical support the implementation of the philosophy of sustainable development of mankind. Green marketing presents important opportunities for industry and economy of the Republic of Serbia. Therefore Serbian companies must re-define the roles of business and products, as well as joint work with government agencies, consumer groups and NGOs. Serbia is becoming aware of environmental issues, but for green marketing businesses, companies, consumers and government still do not pay enough importance.
\end{abstract}

Keywords: sustainable development, green marketing, environmental protection

JEL Codes: R58, 01, M14, Q56 


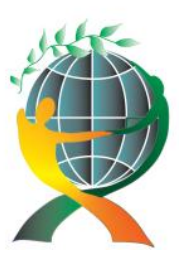

\author{
(online) $=$ ISSN $2285-3642$ \\ ISSN-L = $2285-3642$ \\ Journal of Economic Development, Environment and People \\ Volume 1, Issue 3, 2012 \\ URL: http://jedep.spiruharet.ro \\ e-mail: office jedep@spiruharet.ro
}

\title{
1. Introduction
}

With the development of global industrialization and rapid population growth, problems of threat to the environment were growing, not always with responsible behavior, but also as a result of increasing needs of a growing population on the planet.

At the end of the fifties began to rise and concern for this state of the planet, so the strength has been directed to the adoption of various measures and implement policies to ensure that future generations enjoy the benefits of a clean and healthy living environment. Sustainable development is set as a global philosophy for future generations. In order of his achieving, at the state level, are implementing policies and measures focused on solving specific problems posed by the pollution of the environment, reduce pollution through air, water, slowing down of climate change etc. Today, it is also required from each company and each individual to give contribute to sustainable development. The same case is in Serbia.

Public corporations and individuals employed in them, have a greater responsibility and pressure that must behave as a good "host" and good "citizen" in terms of "good behavior" toward the environment.

A large number of environmental laws throughout the world, and the Republic of Serbia was adopted in order to send a message about the importance of movement to "green wave" around the world.

In some cases in the previous years, the issues of green marketing and the related environment are virtually ignored by corporations and individuals. Hazardous waste and other similar items are considered cost-growing economy. Times have changed and people now realize the consequences of waste products that damage the environment. Today, society recognizes that the preservation of clean air, water and land is more important than searching for cheaper products for consumers and higher profits for companies. Also, the day progresses and the individual consciousness, so that many people are willing to pay more for a product that is environmentally friendly, healthy, safe. Many companies are now interested to be characterized as a "green", so as many investors take account of environmental liability. Some corporations have had to pay to clean up its environmental history of "hostile" behavior. However, most firms have established a good reputation as an "environmentally friendly". To protect the environment, it must be defined in addition to the problem, the way how to resolve the issue. It is necessary to plan, monitor, report

on investment in environmental protection in order to bring the ratio of investment in environmental effects and benefits that implies. 


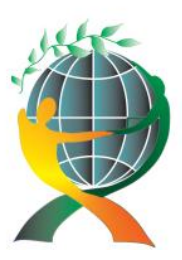

\author{
(online) $=$ ISSN $2285-3642$ \\ ISSN-L = $2285-3642$ \\ Journal of Economic Development, Environment and People \\ Volume 1, Issue 3, 2012 \\ URL: http://jedep.spiruharet.ro \\ e-mail: office jedep@spiruharet.ro
}

\title{
2. Environmental Pollution
}

Environment, and the Ecology has many different definitions, and in symbiosis of all of them we can conclude that this term actually refers to an environment where they are, live and work all living beings, including man. As it has been pointed out by all living beings with their environment generate some interaction, but also living things affect each other. So they act on the environment (reaction), the environment act on them (action) and mutual (coactions).

In relation to the environment, certainly the biggest problem that appears is its pollution. Man with his own lifestyle and behavior, affects the environment, and not always positive. Technology development and changing lifestyles in the modern sense, leads to different production processes and products which as a result have environmental pollution. So, the man through the processes of production of different products leads to pollution of their environment. Very often the products themselves are sources of pollution. All this leads to unwanted changes of environmental factors, such as. climate change or changes in water quality, air, which leads to a change in the quality of life of living beings. Today, at the level of environmental pollution are talking about the issues that have global characteristics. So we can say that global problems of environmental pollution can be divided into problems related to pollution of the atmosphere, water, soil, biodiversity loss, waste and the risks that all human activity carries, such as risk from accidents, radiation, chemicals, genetic modified organisms ... But also through the problems that are the result of the increased volume of trade globally. There is almost universal agreement about the current state of the environment that can be characterized as an ecological crisis, environmental crisis, environmental crisis, etc. The causes that led to the appearance of this crisis are almost entirely attributed to a man

In the broadest terms, saying, two civilization processes led to the disturbance of the environment:

- Population growth on earth

- Economic development and those associated with the fast pace of industrialization

So, other than those described environmental pollutions, these processes have led to the exploitation of natural resources and disrupted the process in nature. Man in using these resources for their own purposes, both directly, so as caused by the increase in population in the country, so as through the production of such goods that require further use of energy, such as cars for example leads to their exhaustion. This raises the question whether it can be indefinitely, and whether those resources are unlimited. The answer to this question is unfortunately negative. There are resources that are renewable, such as forests for example, and those that cannot be renewed as oil or fossil fuel. So, moderation in consumption and utilization of natural recourses presents a major problem for mankind, but at the same time a great challenge. 


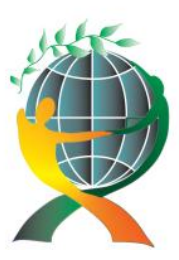

\author{
(online) $=$ ISSN $2285-3642$ \\ ISSN-L = $2285-3642$ \\ Journal of Economic Development, Environment and People \\ Volume 1, Issue 3, 2012 \\ URL: http://jedep.spiruharet.ro \\ e-mail: office jedep@spiruharet.ro
}

\title{
3. Sustainable Development
}

This rapid development of industrialization of humanity, has been retreated with it serious problems that may threaten the future existence of human life on earth. In the middle fifties with increasing concerns about environmental conditions and direction of solving the problems leads to their first observation and definition, and then how to solve them through appropriate systems of environment. In this process, ecological management gets its outlines as a system of environmental management. The concept that presents a general framework for environmental management and the main response to the environmental crisis is sustainable development. Sustainable development is described as development that satisfies the needs of present generations without compromising those opportunities for future generations. ${ }^{1}$ So, sustainable development actually, is a general aim at the global level. It is clear that this aim cannot be achieved without consideration of what actually makes the right of future generations, the measures to be implemented on the way, and their determination and control through integration of policy and law environment in all sector policies.

Economic parameters have priority in the debate on sustainable development. ${ }^{2}$ In other words, increased economic activity actually have for the consequence the exploitation of natural resources, with whom it becomes rare and very important for the economy in general. So, the biosphere actually is an environment in which the economic processes take place, as an important factor, so its protection must be included in the calculation of the economic process. It follows that it is necessary to establish the economic parameters to measure sustainability. All analysis made for individual countries show a direct link between economic parameters and environmental conditions. ${ }^{3}$ Philosophy of sustainable development and its promotion, as a result of the late eighties, actually represents a turn in the conception of environmental protection, through the basic idea of linking development policies and development in general with environmental problems. The issue of integration of environmental policy into sector policies is a key element in understanding sustainable development. Witnesses to this are reports on the environment which are prepared by the main international organizations and individual countries and through consideration of the environment by examining the situation in certain sectors such as energy, agriculture, industry, forestry, fishing, transport, tourism...

The modern concept of sustainable development is not determined only by the economic sizes, already includes the economic, social, cultural and ecological component. The development of ecological

\footnotetext{
${ }^{1}$ Rio Declaration on Environment and development, adopted at the UN conference on Environment and Development, Rio de Janeiro in 1992, principles 3rd

${ }^{2}$ Todić D, Environmental management in conditions of globalization, Megatrend University, Belgrade 2003, p. 121

${ }^{3}$ Encouraging enviromentally sustainable growth: experience in OECD countries, ECO/WKO (2001), OECD
} 


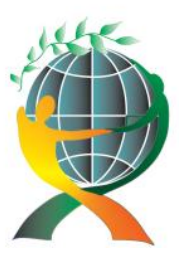

\author{
(online) $=$ ISSN $2285-3642$ \\ ISSN-L = $2285-3642$ \\ Journal of Economic Development, Environment and People \\ Volume 1, Issue 3, 2012 \\ URL: http://jedep.spiruharet.ro \\ e-mail: office jedep@spiruharet.ro
}

consciousness of humanity has been affected the progress in solving environmental problems, because of the human participation in taking the active and passive care for the environment. Since the sixties of the last century, in many countries in the world, in the industry emissions of harmful substances into air and water are reduced, and were identified clean warehouses with toxic materials. ${ }^{4}$ Also, with the adopting regulations, the use of unhealthy chemicals is restricted. The very concept of "sustainable development" is relatively new, but the ideas contained in it can be found in the past. When the sustainable development is taken for serious, as a result drastic demands for change in all spheres of life of every individual accrues. Changes are related to changes in our spending habits (which in itself is already hard enough), and the change of consciousness in the field of economics, politics and society. The term of sustainable development usually is related with environmental protection, planning of social development, environmental, economic and political issues. The concept of sustainable development presents a new development paradigm, a new strategy and philosophy of social development. Sustainable development also combines concern for the wild life on the planet Earth and the preservation of the capacity of natural systems (natural resources) to social and environmental challenges with who is faced every society, country and humanity as a whole. Challenges that come with the vulnerability of the environment in particular affect to actuality of sustainable development. Some of these challenges are: global warming, ozone layer depletion, "greenhouse effect", the disappearance of forests, conversion of arable land in the desert, the occurrence of acid rain, extinction of animal and plant species.

The fact is that today the issue of sustainable development, protection and preservation of the environment became the dominant issue on the world stage, with special emphasis on the application of the principle of prevention. Namely, if we consider environmental risk we need to know that it is a complex quantity that describes the product of probability of harmful events that affect the basic factors of pollution of the environment, safety and human health and the expected size of these events result in the one closed (rounded) system of the environment during the one time interval or during certain missions.

The concept of sustainable development was first mentioned 1982nd at the conference in Nairobi. General Assembly of the United Nations in 1983, has approved the Resolution on taking the initiative to establish the World Commission on Environment and Development, and issued the report "Our Common Future" in 1987, which pointed out the consequences of uncontrolled demographic and economic growth, and hence the need to define the concept of sustainable development. ${ }^{5}$

\footnotetext{
${ }^{4}$ Petrović N, "Environmental Management", Newpress, Smederevo, 2007, p. 56

${ }^{5}$ Petrović N, "Environmental Management", Newpress, Smederevo, 2007, p. 59
} 


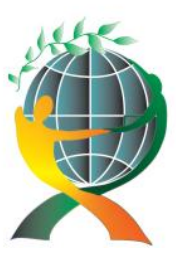

\author{
(online) $=$ ISSN $2285-3642$ \\ ISSN-L = $2285-3642$ \\ Journal of Economic Development, Environment and People \\ Volume 1, Issue 3, 2012 \\ URL: http://jedep.spiruharet.ro \\ e-mail: office jedep@spiruharet.ro
}

At the second UN Conference on Environment and Development in Rio de Janeiro in $1992^{\text {nd }}$ the following documents are approved: ${ }^{6}$

- Rio Declaration on Environment and Development;

- Convention on Climate Change;

- The Convention on Biological Diversity;

- Non-binding document: Principles of management, protection of the sustainable development of all types of forests;

- Agenda 21 (instruction for the implementation).

There are two categories of natural resources: renewable resources: geological resources (mineral resources: metal ores, non-metals and energy resources: coal, oil and gas) and renewable resources: wildlife, water, air, sunlight, wind and tidal energy.

Biodiversity is now under tremendous pressure of various intensities and various factors compromising. Many plant and animal species are endangered, threatened by extinction risk. Some are even completely lost. Biodiversity provides us with not only material wealth, but the spiritual health, the base of a healthy environment and sustainable development. Conservation and sustainable use of biodiversity should be a main concern of humankind, how at the global, so as and regional and local level. The main cause's threats of biodiversity are a global changes (climate, ozone depletion, and the negative effects of greenhouse gases), air pollution, water and land. ${ }^{7}$

There is no single and generally accepted definition of sustainable development. However, there is agreement on the need to introduce this concept and awareness of the reasons for its creation. The most commonly quoted definition of sustainable development is the report "Our Common Future" that has been composed on the call made by the United Nations World Commission on Environment and Development (the Brundtland Commission) in $1987^{\text {th }}$. The term was used by the Brundtland Commission which coined what has become the most often-quoted definition of sustainable development as development that "meets the needs of the present without compromising the ability of future generations to meet their own needs." ${ }^{8}$ This is an elegant and easily understood definition that explains the concept of sustainable development in general, starting from the first term, and without going into detailed explanations. According to another definition, sustainable development implies a balance between resource consumption and capacity of natural systems to meet the needs of future generations.

A comprehensive definition of sustainable development reads: Sustainable development is an integral economic, technological, social and cultural development, in line with the needs of protection and

\footnotetext{
${ }^{6}$ Petrović N, "Environmental Management", Newpress, Smederevo, 2007, p. 58

${ }^{7}$ Kosović, M. S. (2010). Sustainable development of water resources and biodiversity. Ecologica, 17(59), 415-418.

${ }^{8}$ World Commission on Environment and Development (WCED), Our Common Future, Oxford 1987, p. 43
} 


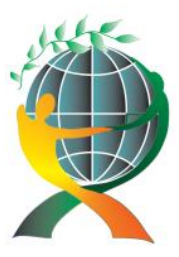

\author{
(online) $=$ ISSN $2285-3642$ \\ ISSN-L = $2285-3642$ \\ Journal of Economic Development, Environment and People \\ Volume 1, Issue 3, 2012 \\ URL: http://jedep.spiruharet.ro \\ e-mail: office jedep@spiruharet.ro
}

improvement of environment, which allows current and future generations to meet their needs and to improve quality of life.

However, the precise meaning of the concept of sustainable development is the subject of extensive debate. There are authors who instead of the term "sustainable development", rather talk about the term "sustainability" and the term "sustainable development" reserve for specific development activities.

In a language sense the term "sustainable development", is some wise inappropriate and inaccurate, or at least, we can make a question what it means. Thus, for example, it raises the question of how can "maintain" something that is subject to constant change - because the "development" implies change, i.e. growth, stagnation or decline. The essence of the concept of sustainable development is based on the principle of intergenerational justice, i.e. Intergenerational equity. This principle refers to the inheritance of the same environmental condition in-between two generation. Disregard of this principle is the damage of the environment of one generation which is transferred to the future generations. ${ }^{9}$

The concept of sustainable development has multiple components. Francesco di Castri, a biologist and director of research at the French National Center for Scientific Research, has defined four components of sustainable development: the economy (industry), society, culture and environment.

\title{
4. Green Marketing
}

When it comes to new marketing concepts, efforts are directed to carefully selected customers, whether it comes to individual or groups, to whom the products or services are adapted, but with interaction of all other participants, create and delivers new, increased value. ${ }^{10}$

Green marketing is the marketing of products that are represented as a safe for human health and safety, as well as its environment, which also should contribute to sustainable development. Green marketing refers to the efforts of organizations to produce, pack, promote and sell of products that are appropriate and acceptable for the individual and the environment. Green marketing includes a wide range of activities including product modification, production process, packaging, promotion and sales, with the aim of delivering healthy, environmental, safe, nutritionally valuable products to the consumers.

First of all, activities in terms of green marketing, anyhow, we must locate and identify the target green consumers, then assess how is the group informed and what kind of additional training is needed to extend or reinforce it. When we observe the demographics of buyers of environmentally acceptable, organic

\footnotetext{
${ }^{9}$ Petrović N, "Environmental Management", Newpress, Smederevo, 2007, p. 59

${ }^{10}$ Radnović B, Ilić M, "Custumer relationship management CRM software solutions and market-oriented enterprises", Proceedings of E-commerce 2008, Palić, 2008.
} 


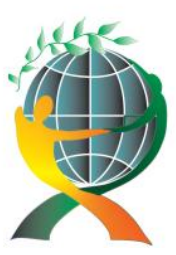

\author{
(online) $=$ ISSN $2285-3642$ \\ ISSN-L = $2285-3642$ \\ Journal of Economic Development, Environment and People \\ Volume 1, Issue 3, 2012 \\ URL: http://jedep.spiruharet.ro \\ e-mail: office jedep@spiruharet.ro
}

products, women are more interested in the environment than men, more often are buying organic produce and more engaged in sorting waste for recycling. However, men and women are equally interested in their health, and equal representation in the activities of preserving the environment. Also, people with higher incomes and education levels, and therefore greater access to information, often pay more attention to organic products and the environment. Psychological indicators of consumers tell us that people with conservative values do not want to complicate life with the changes or do not want to be part of something that does not comply with basic standards and therefore they not open to changes in standards and purchase green products. Observing the behavior of customers who use green products to a large extent, showed that they largely influenced by the opinions of others, states and environmental groups, they also have a strong identity and high degree of concern for themselves and for their environment. Unlike them, customers who buy less green products are of the opinion that it is hard to find these products on the market. The group of customers under the popular name of "green activists" is definitely the target group, because they have the highest level of education, work on high-skilled jobs (middle and senior management, intellectuals, scientists and artists) and have the highest incomes. It should be taken that they also often show great skepticism about the promotional and marketing claims. Green marketing, environmental marketing and sustainable marketing are different in terms of terminology, but substantially with similar meaning. They should not be understood only as a possible profit potential, where the attribute verdancy or the environmental suitability is adding to product, and marketing activities use them for commercial benefit, but should kept in mind the approach that is more complex, and in the long term business more efficient, including: fundamental changes in the company by defining the basic strategy for the company, marketing strategy, organizational structure and most importantly promotion of eco-management. ${ }^{11}$

With the growth rate of economic development the most developed part of the world community, the issue of protection of the environment is becoming increasingly important. So, the concept of deepening marketing business with the concept of green marketing and philanthropic marketing concept arise, causing the emergence of social marketing. In addition, green marketing is the primary segment of social marketing, because it covers the protection and preservation of the values necessary for survival, existence and development of man as a human being. This reflects the philosophy of practical support for the implementation of sustainable development of humanity. ${ }^{12}$

To produce significantly greener products, new and cleaner products, equipment and technology must be developed. Today we are faced with the growth of innovative solutions "clean technology". Successful development of new green products requires high levels of communication and integration, good information, support from top management and benchmarking. Set of controllable tactical marketing tools

\footnotetext{
${ }^{11}$ Ilić, M.M.. "SWOT analysis and eco-marketing." Marketing 28.1 (1997): 41-46.

${ }^{12}$ Pecić, L. "Environmental protection and green marketing." Quality 20.5-6 (2010): 79-81.
} 


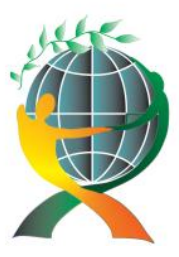

\author{
(online) $=$ ISSN $2285-3642$ \\ ISSN-L = $2285-3642$ \\ Journal of Economic Development, Environment and People \\ Volume 1, Issue 3, 2012 \\ URL: http://jedep.spiruharet.ro \\ e-mail: office jedep@spiruharet.ro
}

such as product, price, place, promotion, which one company combines to respond to the demands of the green market is of great importance for the management of companies. ${ }^{13}$

If we look at the company on the top of the green trend we will recognize their potential for business and profits, as well as their contribution to environmental protection. These successful companies do not sell only the products to its customers and gets profits from that, but rather focuses its own corporate commitments to care for the environment. Unlike conventional producers, most successful green companies direct their customers, or in advance know what have to be done and how to offer to the customers an environmentally acceptable product. Such companies are willing to cooperate openly with customers, government and non-governmental organizations and institutions. They simply demonstrate to its employees, customers, suppliers and others that they want to worry about. Greenest companies are prepared to deal with care of the natural environment. Companies that patiently offer to the greenest consumers truly healthy, safe, nutritionally valuable products and innovative solutions and truly care about the environment, can expect to be most successful in the future. ${ }^{14}$

\title{
5. Experiences from the Republic of Serbia
}

For successful economic development of Serbia, there are necessary changes at the same time, in many areas. The basis of competitiveness of the Serbian economy has to be changed. The above stated require changes, how it refers to marketing strategies of organizations, it refers to the overall business environment in Serbia. To enhance the marketing activities of companies from the Republic of Serbia it is necessary among other things: acceptance and application of the science of marketing in organizations, rather than relying on intuition in decision-making, holistic development of internal marketing, development of marketing relationships with partners such as marketing management and customer relations. Today, in the Republic of Serbia marketing managers that are planning the implementation of modern marketing must know that the modern marketing faces many challenges that affect on business.

Important changes in the modern marketing organization in terms of globalization are:

1. From transactional to relational marketing,

2. From the traditional system to creating a unique value with customers

3. From profit-orientated and sustainable marketing (increasing emphasis is given to green marketing).

Proactive companies today can achieve a competitive advantage by position and differentiation on the basis of:

\footnotetext{
${ }^{13}$ Čajka, Z.. "'Green marketing - a concept of green product." Ecologica 12.44 (2005): 43-47.

${ }^{14}$ Čajka, Z.. " Green marketing - a challenge for the future. " Business Policy 33.1 (2004): 55-56.
} 


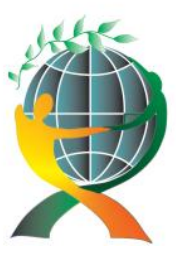

\author{
(online) $=$ ISSN $2285-3642$ \\ ISSN-L = $2285-3642$ \\ Journal of Economic Development, Environment and People \\ Volume 1, Issue 3, 2012 \\ URL: http://jedep.spiruharet.ro \\ e-mail: office jedep@spiruharet.ro
}

1. Relational marketing,

2. Together to create unique value with customers and other business partners and

3. Sustainable development (increasing emphasis on the production and distribution of healthy, safe, nutritionally valuable products). ${ }^{15}$

Modern market-oriented companies in the Republic of Serbia are increasingly trying to align their operations with sustainable development Strategy of Republic of Serbia. Sustainable Development Strategy of the Republic of Serbia bases its decision in accordance with the requirements of European Integration: A Strategy for Sustainable Development of the European Union, adopted 2001th and revised the 2006th with The Lisbon Strategy and the European Union. Sustainable Development Strategy of Serbia is in line with the United Nations Millennium Development Goals and National Development Goals in Serbia, which the Government of the Republic of Serbia adopted during the 2006th.

Sustainable Development Strategy of the Republic of Serbia is in compliance with existing sector strategies:

1. National Employment Strategy;

2. Strategy for development of energy Republic of Serbia by 2015;

3. Strategy for development of agriculture in Serbia;

4. Strategy for tourism development;

5. Strategy for Encouraging and Developing Foreign Investment;

6. National strategies for solving problems of refugees, displaced and internally displaced people;

7. Strategy for public administration reform;

8. Strategy for development of social welfare;

9. National strategies to fight corruption;

10. Strategy for local sustainable development;

11. Strategy for Small and Medium Enterprises;

12. Strategy for reform the health care system - better health for all in the third millennium;

13. Strategy for forestry development;

14. Waterpower engineering basis Serbia 2002 - 2012;

15. National Waste Management Strategy;

16. National Plan for children action;

17. National strategies to combat HIV / AIDS;

18. Strategy for development of vocational education;

19. Strategy for development of adult education;

${ }^{15}$ Rakić, B., Rakić M, "The application of marketing in organizations and the Serbian economy." Economic perspectives 12.3 (2007): 481-494. 


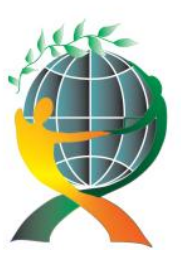

\author{
(online) $=$ ISSN $2285-3642$ \\ ISSN-L = $2285-3642$ \\ Journal of Economic Development, Environment and People \\ Volume 1, Issue 3, 2012 \\ URL: http://jedep.spiruharet.ro \\ e-mail: office jedep@spiruharet.ro
}

\title{
20. Strategy for Regional Development and Action Plan.
}

Of course, today when it is mentioned sustainable development in Serbia increasingly more in business theory and practice of modern market-oriented companies also is mentioning the green marketing, and the necessity of its implementation in the overall business practices of companies from the Republic of Serbia, especially those that already operate or want to do business in the highly demanding European Union market.

It may be noted that the concept of green products, the related companies and green marketing in the Republic of Serbia is in its infancy. It is important to develop a sense of environmental responsibility, both within the company and for each employee and clearly communicated to customers. Does this mean the beginning of placing recycling bins on each floor of a company or an ambitious building of green office building, each company can decide itself in accordance with their capabilities, but the employees within the company must comply with environmental vision, goals and strategies of management? It is observed that in recent times and there is a change in values and allocation of new consumer segments where the quality is more important than quantity, in the short term is not important as long term and not thinking it through more "me" but by "we." In line with this new vision of modern market-oriented companies will have to follow this modern thinking of the consumer society.

Since the production of green products and the introduction of green standards in the companies is financially demanding, it is important to find a way to these costs, at least initially, be reduced to a minimum, as it would not be too much reflected in the price of goods apropos to the domicile of the company Republic of Serbia, who want to introduce green concepts can be internally and externally be competitive on the market. It is also necessary to educate consumers and the target segment of what is necessary for the development of green products and all of its benefits to green price compared to the green quality were relevant and viable in the eyes of consumers. It is unrealistic to expect consumers to develop and present cost of materials for green products, because the green concept is still in its infancy, and the benefits continue, at least so it seems, that they are not clearly conceptualized and explained.

Clearly, the positioning of each, including the green products, is necessary to justify the price, but also positioning of the company itself as market leader. From this it naturally follows, and excellent positioning in the value system of the customer. What makes a product so specific and whether there is targeted group of customers? What makes it practical and affordable? In the positioning should not rely on the environmental benefits, but it should be qualified as value-added products. In short, the only reference to a person's environmental awareness will not sell the product. They are still the primary criteria for physical accessibility in the purchase of products, price and comfort, while ecology is still secondary, to the most customers, even 


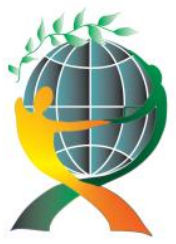

\author{
(online) $=$ ISSN $2285-3642$ \\ ISSN-L = $2285-3642$ \\ Journal of Economic Development, Environment and People \\ Volume 1, Issue 3, 2012 \\ URL: http://jedep.spiruharet.ro \\ e-mail: office jedep@spiruharet.ro
}

though from day to day awareness of environmental, healthy, safe, nutritionally valuable, products and their significance for consumers in the Republic Serbia is growing. Also, it is important to emphasize that this large contribution from many successful global companies operating in the Serbian market, such as LaFarge cement factory - Beočin, Carlsberg Brewery - Celarevo Sartid steel - Smederevo .

Now that we are generally at the beginning of the placement of green products need in the Republic of Serbia, we need to educate consumers in that direction and implement knowledge of ecological, healthy, safe, nutritionally valuable products, in the framework of contemporary marketing campaigns. It is necessary to emphasize the practical benefits to the consumer promotional messages on the ecological product. A large number of green products have become part of the massive use because of its practicality, such as for example energy-efficient machines and organic food. They should not only emphasize the environmental benefits, but above all a practical value for users of green products.

\title{
6. Conclusion
}

Today, in a time of global economic crisis, the issue of sustainable development is even more topical. There is a per se and the additional question, how to overcome the crisis period, but also a way to preserve scarce natural resources. This is certainly not easy. However, in recent times, to the market oriented companies are imposing a relatively new concept - the concept of green marketing. It is a concept that requires a green company that manufactures, distributes and sells green products. Being green means being capable of at every stage of the process to implement green management philosophy, which includes green product, green pricing, green and green channels of distribution and promotion.

The goal is to offer consumers a healthy, safe, environmentally friendly, nutritionally valuable product and at the same time to achieve sustainable development. Achieving sustainable development by implementing the concept of green marketing will require major changes in most companies from the point of planning a green product, through its production, forming a green pricing, distribution channels, green and green promotions. Is demanding, but it certainly shows the cost-effective, in every sense. This is supported by the fact that only the development of environmental industries and green companies withstand global economic crisis.

Republic of Serbia is becoming aware of environmental issues; it is also one of the essential prerequisites for entry into the European Union. However, it seems that there is still green with a marketing company, and perhaps even more consumers on the other hand, do not attach enough importance. But what is encouraging is that in the Republic of Serbia continuously make progress in raising awareness of management of successful companies and consumers about the necessary synergy of green marketing and sustainable development and the necessary environmental, healthy, safe, environmentally, nutritionally valuable products. 


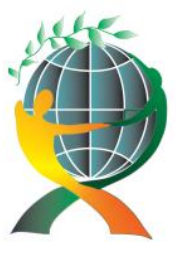

\section{References}

[1] Čajka, Z., "Green marketing - a challenge for the future." Business Policy 33.1 (2004): 55-56.

[2] Čajka, Z.. "Green marketing - a concept of green product." Ecologica 12:44 (2005): 43-47.

[3] Encouraging environmentally sustainable growth: experience in OECD countries, ECO / WKO (2001), OECD, 2001

[4] Ilić, M., Radnović B, .. "SWOT analysis and eco-marketing." Marketing 28.1 (1997): 41-46.

[5] Ilić, M.M.. "SWOT analysis and eco-marketing." Marketing 28.1 (1997): 41-46.

[6] Kosović, M. S. (2010). Sustainable development of water resources and biodiversity. Ecologica, 17 (59), 415-418.

[7] Mihajlović, D. \& Živković, S. (2010). Global ecological and economic problems in the Third Millennium. Ecologica, 17 (59), 437-440.

[8] Pecić, L.. "Environmental protection and green marketing." Quality 20.5-6 (2010): 79-81.

[9] Petrović N, "Environmental Management", Newpress, Smederevo, 2007.

[10] Radnović B, llić M, "Customer relationship management CRM software solutions and market-oriented enterprises", Proceedings of E-commerce 2008, Palić, 2008.

[11] Radnović B., Ilić M, Živković Z, Corporate Social Responsibility and the nonprofit sector - and unethical marketing strategy or genuine concern, 3rd International Conference of Economic Sciences, Kaposvar 2011th

[12] Rakić, B., Rakić M, "The application of marketing in organizations and the Serbian economy." Economic perspectives 12.3 (2007): 481-494.

[13] Rio Declaration on Environment and development, adopted at the UN conference on Environment and Development, Rio de Janeiro in 1992.

[14] Todić D, Environmental management in conditions of globalization, Megatrend University, Belgrade 2003.

[15] World Commission on Environment and Development (WCED), Our Common Future, Oxford 1987 